\title{
Milk Production and Constituents of Beef Cows with Different Breed Compositions
}

Rodrigo C. C. Azambuja ( $\square$ rodrigoccdeazambuja@gmail.com )

Universidade Federal de Pelotas https://orcid.org/0000-0003-0938-1105

\section{Pedro F. Rodrigues}

Universidade Federal de Pelotas

\section{Leonardo M. Menezes}

Universidade Federal de Pelotas

\section{Rodrigo F. Costa}

Universidade Federal de Pelotas

Bruno B. M. Teixeira

Universidade Federal de Pelotas

Fabio S. Mendonça

Universidade Federal de Pelotas

Renata W. Suñé

EMBRAPA Centro de Pesquisa em Pecuaria Sul

\section{Isabella D. B. Silveira}

Universidade Federal de Pelotas

\section{Fernando F. Cardoso}

EMBRAPA Centro de Pesquisa em Pecuaria Sul

\section{Research}

Keywords: Angus, beef cattle, bovine, Caracu, crossbreeding, Nellore

Posted Date: August 17th, 2020

DOl: https://doi.org/10.21203/rs.3.rs-58097/v1

License: (c) (1) This work is licensed under a Creative Commons Attribution 4.0 International License.

Read Full License 
2

3 Rodrigo C. C. Azambuja ${ }^{1 *}$, Pedro F. Rodrigues ${ }^{1}$, Leonardo M. Menezes ${ }^{1,2}$, Rodrigo F. Costa ${ }^{1}$, 4 Bruno B. M. Teixeira ${ }^{1}$, Fabio S. Mendonça ${ }^{1}$, Renata W. Suñé ${ }^{3}$, Isabella D. B. Silveira ${ }^{1}$ and Fernando F. Cardoso ${ }^{3}$

6

$7 \quad{ }^{1}$ Department of Animal Science, Federal University of Pelotas, CEP 96010-900 Pelotas,

$8 \quad$ RS, Brazil

$9 \quad{ }^{2}$ Agro-industrial Technology College, University of Rio Grande do Sul State, CEP 97573-011

10 Sant'Ana do Livramento, RS, Brazil

$11{ }^{3}$ Brazilian Agricultural Research Corporation, Embrapa Pecuária Sul (South Livestock), CEP 12 96401-970 Bagé, RS, Brazil

13 Correspondence: rodrigoccdeazambuja@gmail.com 
Abstract

Background: There are two classes of factors that affect cow milk production and, as a consequence, the performance of calves: environmental and genetic factors. Considering the importance of milk production of beef cattle, it is essential to measure the milk production of such cows. However, such estimation presents some difficulties, especially when cows are raised exclusively in a grazing regime. This study aimed to evaluate the milk production and the nutritional composition of beef cows from eight different breed compositions (Angus: ANAN, Hereford: HHHH, Nellore: NENE, Hereford-Angus: HHAN, Angus-Hereford: ANHH, Nellore-Angus: NEAN, Angus-Nellore: ANNE, and Caracu-Angus: CRAN) raised under continuous natural pasture grazing, besides evaluating the calves' adjusted weight at 210 days until weaning.

Results: NEAN cows were the most productive but did not differ from ANNE, ANHH, and CRAN, with estimated average yields of $6.2,5.97,5.93$ and $5.86 \mathrm{~kg} / \mathrm{day}$, respectively, throughout the lactation period. NENE cows presented the lowest yields, with a daily average of $4.61 \mathrm{~kg}$, although this value did not differ significantly from those of HHHH, ANAN and HHAN cows, which had means of 4.67, 4.79 and $4.84 \mathrm{~kg} /$ day, respectively. Calves of CRAN, NEAN, and ANNE cows were heavier than calves of ANAN, HHAN, HHHH, and NENE cows at weaning, not differing from ANHH cows, which in turn also had heavier calves than $\mathrm{HHHH}$ cows. NEAN, ANNE, HHHH and NENE cows had higher concentrations of total solids in milk than ANAN and ANHH.

Conclusions: In conclusion, as expected, the crossbreeding of genetically more distant breed increases the milk production of beef cows. Therefore, for cow-calf operations in a subtropical climate, crossbreeding between Angus and Nellore or Caracu can be used as a genetic tool to increase cow maternal ability, through greater milk production and nutrient content, and consequently yielding heavier calves at weaning. 
Key words: Angus, beef cattle, bovine, Caracu, crossbreeding, Nellore

\section{Background} cattle production due to a positive correlation with calf weaning weight [1]. Studies have shown that up to $40 \%$ of changes in calf weight during weaning are attributed to the dam's milk production $[2,3]$ and the constituents of the milk produced $[4,5]$.

There are two classes of factors that affect cow milk production and, as a consequence, the performance of calves: environmental and genetic factors. As for environmental factors, the most commonly report as relevant ones are the age of the cow at calving, the year, the time of calving during the calving season, and especially the nutritional level to which the cows are subjected $[4,6,7]$. Among non-environmental or genetic factors, the breed composition of cows, usually expressed in terms of breed percentages or genetic groups, stands out. In the search for more productive and efficient dams, some studies used crossbreeding aiming to obtain the benefits of heterosis and complementarity, thus obtaining satisfactory results concerning the milk production of beef cows. Some studies found that heterosis influenced milk production $[4,8,9]$ and that crossbred calves are normally heavier at weaning $[10,11]$

Brown et al. [4] pointed out that not only the volume of milk produced is important, but also the quality of such milk, i.e., whether the nutrients that make up this feed show adequate proportions for the complete initial development of calves. Milk composition may be influenced by the cow's breed composition, stage of lactation and feeding level to which the cow is subjected $[4,12,13]$.

Considering the importance of milk production of beef cattle, it is essential to measure the milk production of such cows. However, such estimation presents some difficulties, 
especially when cows are raised exclusively in a grazing regime. In this context, two techniques are the most used: difference in calf weight before and after nursing or direct measurement by mechanical or manual milking [14-17]. Evidence shows that mechanical milking can be more accurate than the indirect method, however, factors such as the number of cows, infrastructure, and labor can influence the choice of technique [16]. Considering the importance of a more accurate estimate of the individual production of each cow, it is necessary to compare the estimates obtained by each method.

This study was conducted aiming to evaluate the production and the nutritional composition of beef cows of eight breeds (Angus, Hereford, Nellore, Hereford-Angus, AngusHereford, Nellore-Angus, Angus-Nellore and, Caracu-Angus) in continuous natural grazing, besides evaluating the calves' adjusted weight at 210 days until weaning.

\section{Methods}

\section{Characterization of animals and conditions}

The study was conducted at the Embrapa Southern Livestock Research Center (CPPSul) of the Brazilian Agricultural Research Company (Embrapa) located in the municipality of Bagé, in the Campanha Region, Rio Grande do Sul (RS) State. All the procedures performed in this study were approved by the Animal Experimentation Ethics Committee of the Federal University of Pelotas, Pelotas, Brazil (Protocol No. 9288).

We collected 320 records of cows aged 3 to 6 years from eight breed compositions, with the sire breed is listed first, as follows: 45 Angus (ANAN), 26 Hereford (HHHH), 16 Nellore (NENE), 57 crossbred 1/2 Hereford 1/2 Angus (HHAN), 27 crossbred 1/2 Angus 1/2 Hereford (ANHH), 53 crossbred 1/2 Nellore $1 / 2$ Angus (NEAN), 30 crossbred $1 / 2$ Angus 1/2 Nellore (ANNE) and 66 crossbred 1/2 Caracu 1/2 Angus (CRAN). 
old cows weaning the first calf, 4.1 means 4-year-old cows weaning the first calf, 4.2 means 4year-old cows weaning the second calf, 4.18 means 4-year calves weaning the second calf but that had the first calf at eighteen months of age, 5.2 means 5-year-old cows with the second calf, 5.3 means 5-year-old cows with third calf, 6.3 means 6-year-old cows with third calf, and 6.4 means 6-year-old cows with the fourth calf.

The cows within breed composition were randomized into two groups and mated with Brangus and Braford bulls in December 2009/2010/2011. Initially, artificial insemination was performed at a fixed time using the semen from six Brangus bulls and five Braford bulls, and then a natural mating that lasted 75 days with two Braford bulls and two Brangus bulls in each lot. The calving period was between September and December 2010, 2011 and 2012. The weaning of all calves occurred in May 2011, 2012 and 2013, respectively.

\section{Measurements}

Milk yields were obtained by using two methods: indirectly by the calf weight difference before and after nursing (CWD) [14] and directly by mechanical milking (MM). Using the CWD method, 10 measurements were made at 21-day intervals culminating in weaning. On the day before the evaluation, at $1 \mathrm{pm}$, the calves were separated from the cows and, at $7 \mathrm{pm}$, they were reunited with their dams for 45 min to suck and deplete the milk of mammary glands. Then, the cows were separated from the calves until the following morning and placed in a pasture with water and grass. The next morning, at $7 \mathrm{am}$, the calves were weighed during a fast, put to suck for $45 \mathrm{~min}$, and then weighed again. The difference between the calves' weights before and after nursing was considered as a 12-h milk production, which, multiplied by two, was used to estimate the 24 -h period. For weighing, we used a TRU-TEST electronic scale with a maximum capacity of $1,500 \mathrm{~kg}$ and a precision of $100 \mathrm{~g}$. To minimize 
errors resulting from the excretion of feces and urine between both weighings, the weighings were carried out in the shortest possible time.

The direct evaluation technique performed by MM was performed in three different periods of lactation: beginning (40-60 days), middle (90-110 days) and end (180-210). On the day before milking, the same management was performed, and then we performed the analysis by weight difference pre- and post-nursing. On the following day, at 7:00 am, the milking began on the containment trunk with the application of $3 \mathrm{ml}$ of oxytocin intravenously to facilitate the release of the milk. After the udder was washed and massaged, milking was performed until the udder was exhausted, a process that lasted around seven minutes and was carried out by a FOCKINK AT BVF 200 mobile milking machine. The cows were subdivided according to their date of parturition into lots containing approximately 22 animals. The milk yield in $24 \mathrm{~h}$ was estimated by the equation proposed by Restle et al. [18].

5

$$
M P=\frac{M P M M * 60 \min * 24 h}{T I}
$$

where $M P$ : estimated $24-\mathrm{h}$ milk production (kg/day); $M P M M$ : milk production obtained by MM (kg); and TI: time interval (min) between the last suckling and the milking.

After milking, we collected approximately $100 \mathrm{ml}$ samples, which were sent to an accredited laboratory to determine the percentage of milk fat, protein, lactose, and total solids. Some studies indicate that fat content is also affected by the cow's age and calving time, reasons why milk yields with variable fat percentages were adjusted to a standard, which is $4 \%$ in most countries. Such correction is made using the Gaines and Davidson [19] equation: 
where: $(M P C F)=$ milk production corrected to $4 \%$ fat; and $F=$ observed milk fat percentage. all evaluations and cows with non-standard fat concentrations $(<1$ or $>7 \%)$ were neglected, resulting in the exclusion of five ANAN, two CRAN, nine HHAN, ten NEAN, five HHHH, three NENE, three ANHH, and three ANNE cows. Ferrell [20]:

$$
\operatorname{MPCF}_{(S)}=\frac{S}{a e^{k S}}
$$

where $M P C F_{(S)}=24$-h milk production corrected to $4 \%$ of fat in the week $S$ postpartum; $a=$ curve scale parameter; $k=$ curve shape parameter, indicating lactation persistence; and $S=$ lactation time in weeks. calculate three descriptive values which are characteristic of lactation curves:

$$
\mathrm{W} P=\frac{1}{k}
$$$$
P P=\frac{1}{a k e}
$$

$$
T P 210=\frac{-7}{a k} \times\left(S e^{-k S}+\frac{1}{k e^{-k s}}-\frac{1}{k}\right),
$$


where: $W P=$ week of peak lactation; $P P=$ milk production at lactation peak $(\mathrm{kg}) ; T P 210=$ total milk production in 210 days of lactation.

The persistence of lactation (PER) was defined as the daily linear decrease in milk production between the peak lactation and weaning times [21]:

where, $F P=$ milk production on the last day of lactation; and $D=$ number of days from the peak of lactation to the end of lactation.

The calf weight adjusted at 210 days of age (CW210) by the following equation:

$$
P E R=\frac{(P P-F P)}{D} * 1000
$$

\section{(1)}

$$
C W 210=\left(\frac{W W-B W}{W A}\right) * 210+B W
$$

where $\mathrm{WW}=$ weaning weight $(\mathrm{kg}), \mathrm{BW}=$ birth weight $(\mathrm{kg})$, and $\mathrm{WA}=$ age at the weaning day (days).

\section{Statistical analyses}

The parameters $a$ and $k$, as well as the other variables derived from the lactation curve, were considered dependent variables for each cow and were analyzed in a completely randomized design by using the SAS PROC GLM [22]. The statistical model used to represent the observation was:

$$
Y_{i j k m n}=m+G_{i}+S_{j}+M_{k}+B O_{m}+R T_{n}+e_{i j k m n}
$$


where: $Y_{i j k m n}=$ response variable derived from the lactation curve; $m=$ overall mean; $G_{i}=$ effect of the cow's breed composition (ANAN, CRAN, HHAN, NEAN, ANHH, ANNE, NENE, $\mathrm{HHHH}) ; S_{j}=$ calf sex effect (M, F); $M_{k}=$ parity season effect (beginning/end); $B O_{m}=$ effect of birth order class $(3.1,4.1,4.18,4.2,5.2,5.3,6.3$, and 6.4$) ; R T_{n}=$ bull breed effect (Braford, Brangus); and $e_{i j k m n}=$ experimental error.

The nutritive constituents of the milk were analyzed by repeated measures design using the PROC MIXED of SAS [22]. The statistical model was:

$$
Y_{i j k m n o p}=m+G_{i}+S_{j}+M_{k}+B O_{m}+R T_{n}+P_{o}+G P_{i o}+V_{p}\left(G_{i}\right)+e_{i j k m n o p},
$$

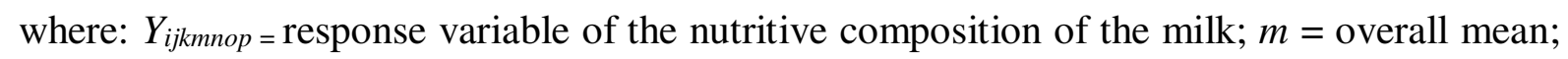
$G_{i}=$ effect of the cow's breed composition (ANAN, CRAN, HHAN, NEAN, HHHH, ANHH, NENE, and ANNE); $S_{j}=$ calf sex effect (Male and Female); $M_{k}=$ parity season effect (beginning and end); $B O_{m}=$ effect of birth order class $(3.1,4.1,4.18,4.2,5.2,5.3,6.3$, and 6.4); $R T_{n}=$ bull breed effect (Braford and Brangus); $P_{o}=$ effect of lactation period (beginning, middle, and end); $G P_{i o}=$ effect of interaction between breed composition and lactation period; $V_{p}\left(G_{i}\right)=$ random effect of the cow within the breed composition; and $e_{i j k m n o p}=$ experimental error.

For comparison of means, the Tukey test was used at a significance level of 0.05 . Partial correlations between measurements free of effects on the model (breed composition, calving order, calf sex, etc.) were obtained by multivariate analysis of variance (MANOVA) using the GLM Procedure [22].

\section{Results and Discussion}

\section{Lactation curve and milk production}



breed composition of the cows in the two methods of evaluation (Table 1). The lactation curve obtained by the MM methodology (Figure 1) shows a greater difference among the analyzed genotypes, unlike the CWD lactation curve (Figure 2). Although there are no inconsistencies, the differences between breed compositions are not so evident in Figure 2.

The TP210 estimated by MM was significantly influenced $(P<0.05)$ by the lactating cow genotype (Table 1), where NEAN cows were the most productive but did not differ from ANNE, ANHH and CRAN, with estimated average yields of 6.19, 5.97, 5.93 and $5.86 \mathrm{~kg} / \mathrm{day}$, respectively, throughout the lactation period. Nellore cows presented the lowest yields during the 210 days of lactation, with a daily average of $4.61 \mathrm{~kg}$, although this value did not differ significantly from those of HHHH, ANAN and HHAN cows, which had estimated means of 4.67, 4.79 and $4.84 \mathrm{~kg} /$ day, respectively.

Albertini et al. [23] reported a significant difference between the averages of NEAN and F1 Caracu-Nellore cows obtained by MM analysis, finding a total milk production corrected to $4 \%$ fat of $1,563 \mathrm{~kg}$ and $1,375 \mathrm{~kg}$, respectively. Such yields are greater than those reported in the present study. On the other hand, Ribeiro et al. [10], also using direct evaluation, but through manual milking of ANAN and ANNE cows, did not find a significant difference $(P>0.05)$ for the milk production corrected to $4 \%$ fat of both genotypes, obtaining averages of 2.9 and $2.1 \mathrm{~kg} /$ day, respectively.

Jenkins and Ferrell [24], using the CWD method, found significant differences in milk productions, which were influenced by cow genotype. These authors reported a superior performance of Angus cows concerning Hereford cows for the parameter total production at 210 days, with yields of 1,423 and 1,191 $\mathrm{kg}$ and averages of $6.78 \mathrm{~kg} / \mathrm{day}$ and $5.67 \mathrm{~kg} / \mathrm{day}$, respectively. Rovira [25] reported an average of $3.8 \mathrm{~kg} /$ day for Hereford cows in a native 
pasture during 212 days, with a total production of $807 \mathrm{~kg}$, below that found by Mendonça et al. [26], who reported a daily average of $4.8 \mathrm{~kg}$ for the same breed.

The differences between total yields in different studies reflect the great influence of environmental and genetic conditions to which beef cows are subjected to. This allows us to outline animal management and breeding strategies to maximize the benefit of maternal ability within the breeding system.

In the genotypes evaluated and, in both situations (i.e. MM and CWD), peak production occurred between the 7th and 11th week of lactation (Table 1). This is consistent with the report by NRC [27] and Rodrigues et al. [15], who found that peak milk production in different genetic groups occurred on average at 8.5 weeks of lactation.

The breed composition of cows influenced the milk production at the lactation peak $(P$ $<0.05)$. ANHH and CRAN cows had higher yields than ANAN, HHAN and NENE cows (Table 1). NEAN and ANNE cows had greater peak production than ANAN and NENE, but not higher than the other breed compositions when the MM method was used. When we observed the results produced by the CWD method, only CRAN cows showed superiority in relation to NENE cows (Table 1). Albertini et al. [23] also found a difference $(P<0.05)$ in production at the peak of lactation according to the genotype of the lactating cow, perceiving a higher production of NEAN cows in relation to NECR cows, which presented averages of 7.8 and $6.3 \mathrm{~kg}$, respectively. The later results are similar to those of our study despite a slightly different comparison basis. Jenkins and Ferrell [20] reported a peak yield of $9.7 \mathrm{~kg}$ for HHAN cows kept on native pastures, while Oliveira et al. [28], performing CWD with Nellore, Nellore-Simental, and Nellore-Limousin cows, found a peak lactation production of 5.0, 8.7 and $6.68 \mathrm{~kg}$, respectively.

CRAN cows presented a lower persistence of lactation when compared to ANAN cows $(P<0.05)$ using the MM method (Table 1$)$. These results are probably associated with higher 
milk production of CRAN cows compared to ANAN cows. In addition, other authors have found that in Brangus cattle [29] and crossbred animals [30] the more productive cows tended to show more expressive decreases in milk production.

The breed of the bull influenced the total production at 210 days $(P<0.05)$ only when analyzed by the CWD method (Table 1). A 10\% higher TP210 was found for cows mated with Brangus bulls than for cows mated with Braford bulls. Estimating production by MM, Restle et al. [18] did not find significant differences between milk yields of Nellore and Charolais cows crossed with Nellore and Charolais bulls, although cows crossed with Nellore bulls produced $8.3 \%$ more than cows crossed with Charolais bulls. Similarly, Mendonça et al. [26], using the CWD method, did not find significant differences in the milk production of Hereford cows that nursed Red Angus or Nellore paternal calves.

The higher milk production of cows suckling crossbred calves may have occurred because of a greater number of feedings per period than pure ones. This is associated with the genetic determination of the calves' temperament and behavior, which, by nursing more frequently, would further stimulate the production of milk by their dams $[14,31]$. Corroborating this, Reynolds et al. [32] found that cows with crossbred calves produced more milk (16\%) than cows with purebred calves. Therefore, our results suggest that CWD evaluation does not only estimate the cow's milk production capacity but that the behavior of the calf also influences cow milk production because of higher milk consumption. Seemingly, the calves out of Brangus sires had a more active nursing behavior when compared to calves of Braford bulls.

We verified an influence of the calving season on total milk production when analyzed by the MM method (Table 2). Cows that calved at the end of the calving season had low total yields $(\mathrm{P}<0.05)$. In contrast, cows which calved during the first half of the calving period had higher yields at the peak lactation period. This can be justified by the variation in climatic 
conditions (e.g. temperature, rainfall and, luminosity) between calving periods because climate directly affects the availability and quality of forages $[9,33,34]$. Therefore, in the present study, cows calving in early spring were favored because this period corresponded to better productivity and quality of regional natural grasses due to a favorable climate [35].

Regarding the calving order, of the nine categories evaluated by the MM method, the cows 3.1 showed lower milk production at the lactation peak than the majority categories (except 4.18 and 4.2) and lower TP210 than almost all other groups (except 4.18, Table 3). Our results match that found in other studies, for example, NRC [36] estimated that cows 2 and 3 years old produce less milk ( 26 and $12 \%$, respectively) compared to cows $\geq 4$ years old; Notter et al. [37] reported that cows of different beef breeds 3 years old produce $19 \%$ less milk than cows 4 years old, and Rodrigues et al. [15] observed that beef cows 3 years old produced less milk than cows 4 and 5 years old. It was expected that younger cows produced less milk because, in addition to meeting the nutritional requirements for maintenance and production, they must meet the growth requirements. Consequently, adult cows show a more favorable energy balance and higher milk production. Usually, milk production increases up to five or six years of age and decreases after eight or nine years of age [14, 29, 38-40].

Despite age being an important factor when it comes to milk production [4], delaying the age of first calving to increase milk production would be unfeasible, because these cows would have a very long unproductive period, increasing costs and decreasing the efficiency and profitability of the production system [41].

In this study, the lactation parameters evaluated by both methods (MM and CWD) were not influenced by the sex of the calf or the year of evaluation $(\mathrm{P}>0.05)$. Similarly, some studies have found that the sex of the calf does not influence the milk production of the cow $[2,3,33$, 40, 42, 43]. However, McCuskey et al. [44] observed a higher milk production of cows nursing males, and Robison et al. [2] found a higher production of cows that suckle females. 
Additionally, higher milk production was reported from heavier lactating cows, regardless of sex [33, 45], and Jeffery et al. [46] found an interaction between the year and sex of the calf in the milk production of beef cows. Evidence shows a divergence between the results of different studies, however, this may be associated with the fact that milk production is more influenced by calf weight at birth than by sex, this is associated with greater milk consumption and greater stimulus in the production of hormones linked to the lactation of heavier calves [26, 47].

\section{Calf performance}

The calf weight (CW210) was influenced by the cow's breed composition. On the other hand, it was not influenced by the bull breed (Table 1). Calves of CRAN, NEAN, and ANNE cows were heavier than calves of ANAN, HHAN, HHHH, and NENE cows at weaning, not differing from ANHH cows, which in turn also had heavier calves than HHHH cows. Such results agree with a corresponding higher milk production of cows, confirming that weaning weight is closely related to the cow's milk production $[3,47,48]$. Several studies have also related weaning weight to maternal milk production regardless of genotypes involved [3, 49]. The correlation between TP210 and CW210 was significant and positive $(P<0.05)$, with a low to moderate magnitude, for both milking methods, MM $(r=0.45)$, and CWD $(r=$ 0.23). This association was also reported in the Caracu, Charolais, Gir, and Nellore breeds in Brazil, showing a positive correlation between mean milk production and weaning weight $(r=$ $0.63-0.73)[3,49]$.

\section{Milk components}

Some genotypes affected the milk components, the averages of the evaluated components are presented in Table 4. The fat content was higher in ANNE, CRAN, HHH, and NEAN cows than in ANAN cows $(P<0.05)$. Protein was higher in NENE and HHHH cows 
than in ANAN, HHAN, ANHHH, and NEAN cows $(P<0.05)$. Concerning the lactose contents, NEAN and ANNE cows showed higher levels than all other genotypes $(P<0.05)$. Finally, for total solids, NEAN, ANNE, HHH, and NENE cows showed higher concentrations than ANAN and ANHHH cows $(P<0.05)$. These results show two phenomena: 1$)$ crossbred cows with higher genetic distance (in this study, NEAN, ANNE and CRAN cows), even with a milk production among the highest, also showed a higher concentration of nutrients, and 2) higher concentration of nutrients in the milk of cows with lower milk production (in this study, HHHH and NENE cows). These findings had already been observed by other authors, Brown et al. [4] observed an effect of heterosis in the production and composition of milk, and Restle et al. [18] observed that more productive cows had lower concentrations of nutrients in the milk.

In the genotypes evaluated in this study, the fat in milk varied from 3.3 to $4.05 \%$, similar to that found in ANAN, Brahman, Angus-Brahman and Brahman-Angus cows (3.1-4.0\%) [4], and lower than that found in NENE cows $(4.3-4.8 \%)[18,50]$. The concentrations of protein in this study (2.9 to 3.3\%) were similar to those reported in ANAN, Brahman, Angus-Brahman and Brahman-Angus (3.3-3.4\%), [4] NENE (2,86-3.6\%) (Almeida et al 2018) and Charolais, Nellore-Charolais and Charolais-Nellore cows (2.86-3.17\%) [51]. Higher concentrations of fat and protein in milk are positively associated with the weight of pre-weaning calves in beef breeds [4].

Lactose is synthesized in the mammary gland and is the main carbohydrate in milk. In this study, the lactose content (4.6-4.86\%) is within that described by the NRC [27], which mention that it can vary from 3.84 to $5.66 \%$. Furthermore, these results are similar to those reported by other studies in NENE (4.36-5.1\%) [50, 52], Charolais $(4.94-5.14 \%)$ [52] and ANHH cows (4.38-5.29\%) [18]. 
A positive correlation was found between total solids and fat $(P<0.05, r=0.91)$ and protein $(P<0.05, r=45)$. Additionally, fat showed a positive correlation with protein $(P<$ $0.05, r=0.20)$ and a negative correlation with lactose content $(P<0.05, r=-0.26)$. This was expected, as total solids include all milk components except water.

Regarding the lactation period, the nutritional contents also changed over time (Table

5). Protein content and total solids had a significant increase $(P<0.05)$ in each period analyzed.

The percentage of fat contents, despite significant differences found only between the first two analyses and the last analysis, indicates a gradual increase due to lactation, unlike lactose contents, which had a significant decrease $(P<0.05)$ at the end of lactation.

Among the milk components, fat varied most during lactation. In General, the percentage of milk fat gradually increases throughout the lactation day and is negatively correlated with cow milk production $[38,53]$, which corroborates the results found here (Table maximum concentration $(5.13 \%)$ at the peak of lactation.

\section{Conclusion} ability, with greater milk production and produced the most nutritious milk among the studied breed compositions. Consequently, such crosses can be adopted in cow-calf operations to produce heavier calves and to increase the productivity of the breeding phase in the extensive natural pasture beef cattle breeding of the Pampa Biome. 
Abbreviations

ANAN: Angus; ANHH: Angus-Hereford; ANNE: Angus-Nellore; CRAN: CaracuAngus; CW210: Calf weaning weight adjusted to 210 days; CWD: Calf weight difference before and after nursing; HHAN: Hereford-Angus; HHHH: Hereford; MM: Mechanical milking; NEAN: Nellore-Angus; NENE: Nellore; PER: Persistence of lactation; PP: 386 Production at the time of lactation peak; TP210: Total production in 210 days of lactation; WP: Week of peak lactation.

Acknowledgments

390 Not applicable. and the data. FSM, RWS and IDBS analyzed the data. All authors have revised and approved 395 the final manuscript.

\section{Authors' contributions}

RCCA and FFC designed the study. PFR, LMM, BBMT and RFC collected samples

\section{Funding}

This study was financed by the Coordenação de Aperfeiçoamento de Pessoal de Nível Superior - Brazil (CAPES, Finance Code 001), Conselho Nacional de Desenvolvimento Científico e Tecnológico - Brazil (CNPq), and Empresa Brasileira de Pesquisa Agropecuária (EMBRAPA).

\section{Availability of data and materials}

All data generated or analyzed during this study are included in this published article. 


\section{Ethics approval and consent to participate}

403

All the procedures performed in this study were approved by the Animal 404 Experimentation Ethics Committee of the Federal University of Pelotas, Pelotas, Brazil 405 (Protocol No. 9288).

406

407

\section{Consent for publication}

408 Not applicable.

409

410

\section{Competing interests}

The authors declare that they have no competing interests.

412

\section{Author details}

${ }^{1}$ Department of Animal Science, Federal University of Pelotas, CEP 96010-900 Pelotas,

RS, Brazil. ${ }^{2}$ Agro-industrial Technology College, University of Rio Grande do Sul State, CEP 97573-011 Sant'Ana do Livramento, RS, Brazil. ${ }^{3}$ Brazilian Agricultural Research Corporation,

Embrapa Pecuária Sul (South Livestock), CEP 96401-970 Bagé, RS, Brazil.

418

419

\section{References}

420 1. Cortés-Lacruz X, Casasús I, Revilla R, Sanz A, Blanco M, Villalba D. The milk yield of 421 dams and its relation to direct and maternal genetic components of weaning weight in beef cattle. Livest Sci. 2017;202:143-9. correlations. J Anim Sci. 1978;47:131-6. 
425 3. Albuquerque LG, Eler JP, Costa MJRP, Souza RC. Milk production and calf performance 426 from birth to weaning in three beef cattle breeds. R Bras Zootec. 1993;22:745-54.

427 4. Brown MA, Brown AH, Jackson WG, Miesner JR. Genotype x environment interactions in milk yield and quality in Angus, Brahman, and reciprocal-cross cows on different

5. Forster KM, Pimentel MA, Moraes JCF. Disponibilidade de energia líquida no leite e desempenho ponderal de bezerros Hereford e Aberdeen Angus do nascimento à desmama. R Bras Zootec. 2010;39:2545-52.

6. Ribeiro ELA, Restle J, Pires CC. Produção e composição do leite em vacas Charolês e Aberdeen Angus amamentando terneiros puros ou mestiços. Pesq Agropec Bras. $1991 ; 26: 1-7$

7. Pimentel MA, Moraes JCF, Jaume CM, Lemes JS, Brauner CC. Produção de leite e

10. Ribeiro ELA, Restle J, Rocha MA, Mizubuti IY, Silva LDF. Eficiência produtiva em vacas primíparas das raças Aberdeen Angus e Charolês. R Bras Zootec. 2001;30:125-32.

11. Calegare L, Alencar MM, Packer IU, Lanna DP. Energy requirements and cow/calf efficiency of Nellore and continental and british Bos taurus x Nellore crosses. J Anim Sci. 2007;85:2413-22. 
12. Holloway JW, Butts WT, Beaver EE, McCurley JR, Peeler HL, Backus WL. Breed $\times$ nutritional environment interactions for beef female weight and fatness, milk production and calf growth. J Anim Sci. 1985;61:1354-63.

13. Liu T, Mays AR, Turner KE, Wu JP, Brown MA. Relationships of milk yield and quality from six breed groups of beef cows to preweaning average daily gain of their calves. $\mathrm{J}$ Anim Sci. 2015;93:1859-64.

14. Rovira J. Reproducción y manejo de los rodeos de cria. Montevideo: Hemisferio Sur; 1974.

15. Rodrigues PF, Menezes LM, Azambuja RC, Sune RW, Barbosa Silveira ID, Cardoso FF. Milk yield and composition from Angus and Angus-cross beef cows raised in southern Brazil. J Anim Sci. 2014;92:2668-76.

16. Edwards SR, Hobbs JD, Mulliniks JT. High milk production decreases cow-calf productivity within a highly available feed resource environment. Transl Anim Sci. 2017;1:54-9.

17. Mulliniks JT, Edwards SR, Hobbs JD, McFarlane ZD, Cope ER. Post-weaning feed efficiency decreased in progeny of higher milk yielding beef cows. Animal. 2018;12:2759.

18. Restle J, Pacheco PS, Moletta JL, Brondani IL, Cerdótes L. Grupo genético e nível nutricional pós-parto na produção e composição do leite de vacas de corte. R Bras Zootec. 2003;32:585-97.

19. Gaines WL, Davidson FA. The effect of advance in lactation and gestation on mammary activity. J Gen Physiol. 1926;9:325-32.

20. Jenkins TG, Ferrell CL. A note on lactation curves of crossbred cows. Anim Sci. 1984;39:479-82. 
21. Jenkins TG, Ferrell CL, Roberts AJ. Lactation and calf weight traits of mature crossbred cows fed varying daily levels of metabolizable energy. J Anim Sci. 2000;78:7-14.

22. SAS. SAS/STAT® 9.2 User's Guide. Cary: SAS Institute Inc.; 2008.

23. Albertini TZ, Medeiros SR, Torres RA, Zocchi SS, Oltjen JW, Strathe AB, et al. A methodological approach to estimate the lactation curve and net energy and protein requirements of beef cows using nonlinear mixed-effects modeling. J Anim Sci. 2012;90:3867-78.

24. Jenkins TG, Ferrell CL. Lactation characteristics of nine breeds of cattle fed various quantities of dietary energy. J Anim Sci. 1992;70:1652-60.

25. Rovira J. Manejo nutritivo de los rodeos de cría en pastoreo. Montevideo: Hemisferio Sur; 1996.

26. Mendonça G, Pimentel MA, Cardellino RA, Osório JCS. Produção de leite em primíparas de bovinos Hereford e desenvolvimento ponderal de terneiros cruzas taurinos e zebuínos. R Bras Zootec. 2002;31:467-74.

27. NRC. Nutrient requirements of beef cattle. 7th ed. Washington: The National Academies Press; 1996.

28. Oliveira VC, Fontes CAA, Siqueira JG, Fernandes AM, Sant'Ana NF, Neto AC. Produção de leite e desempenho dos bezerros de vacas Nelore e mestiças. R Bras Zootec. 2007;36:2074-81.

29. Johnson CR, Lalman DL, Brown MA, Appeddu LA, Buchanan DS, Wettemann RP. Influence of milk production potential on forage dry matter intake by multiparous and primiparous Brangus females. J Anim Sci. 2003;81:1837-46.

30. Minick JA, Buchanan DS, Rupert SD. Milk production of crossbred daughters of highand low-milk EPD Angus and Hereford bulls. J Anim Sci. 2001;79:1386-93. 
31. Das SM, Redbo II, Wiktorsson H. Effect of age of calf on suckling behaviour and other behavioural activities of Zebu and crossbred calves during restricted suckling periods. Appl Anim Behav Sci. 2000;67:47-57.

32. Reynolds WL, Derouen TM, Bellows RA. Relationships of milk yield of dam to early growth rate os straightbred and crossbred calfs. J Anim Sci. 1978;47:584-94.

33. Alencar MM, Ruzza FJ, Porto EJS. Desempenho produtivo de fêmeas das raças Canchim e Nelore. III. Produção de leite. R Bras Zootec. 1988;17:317-28.

34. Bohmanova J, Misztal I, Cole JB. Temperature-humidity indices as indicators of milk production losses due to heat stress. J Dairy Sci. 2007;90:1947-56.

35. Carvalho PCF, Fischer V, Santos DT, Ribeiro AML, Quadros FLF, Castilhos ZMS, et al. Produção animal no bioma campos sulinos. Braz J Anim Sci. 2006;35:156-202.

36. NRC. Nutrient requirements of dairy cattle. 7 ed. Washington: Academies Press; 2001.

37. Notter DR, Cundiff LV, Smith GM, Laster DB, Gregory KE. Characterization of biological types of cattle. VII. Milk production in young cows and transmitted and maternal effects on preweaning growth of progeny. J. Anim. Sci. 1978;46:908-21.

38. Rutledge JJ, Robison OW, Ahlschwede WT, Legates JE. Milk yield and its influence on 205-Day weight of beef calves. J Anim Sci. 1971;33:563-7.

39. Souza EM, Milagres AJ, Regazzi ML, Martinez L, Silva MA. Effects of genetic and environmental factors on milk production of dairy gir cattle in Brazil. R Bras Zootec. 1996;25:889-901.

40. Pimentel MA, Moraes JCF, Jaume CM, Lemes JS, Brauner CC. Características da lactação de vacas Hereford criadas em um sistema de produção extensivo na região da campanha do Rio Grande do Sul. R Bras Zootec. 2006;35:159-68. 
41. Pötter L, Lobato JFP, Mielitz Netto CGA. Análises econômicas de modelos de produção com novilhas de corte primíparas aos dois, três e quatro anos de idade. R Bras Zootec. 2000;29:861-70.

42. Melton AA, Riggs JK, Nelson LA, Cartwright TC. Milk production, composition and calf gains of Angus, Charolais and Hereford cows. J Anim Sci. 1967;26:804-9.

43. Alencar MM. Heritability and effects of milk production on the reproductive efficiency of Canchim cows. R Bras Zootec. 1987;16:163-9.

44. McCuskey A, Daley DR, Bailey CM. Composition and yield of milk from beef-type Bos taurus and Bos indicus X Bos taurus dams. J Anim Sci. 1987;64:373-84.

45. Mallinckrodt CH, Bourdon RM, Golden BL, Schalles RR, Odde KG. Relationship of maternal milk expected progeny differences to actual milk yield and calf weaning weight. J Anim Sci. 1993;71:355-62.

46. Jeffery HB, Berg RT, Hardin RT. Factors influencing milk yield of beef cattle. Can J Anim Sci. 1971;51:551-60.

47. MacNeil MD, Mott TB. Genetic analysis of gain from birth to weaning, milk production, and udder conformation in Line 1 Hereford cattle. J Anim Sci. 2006;84:1639-45.

48. Miller SP, Wilton JW. Genetic relationships among direct and maternal components of milk yield and maternal weaning gain in a multibreed beef herd. J Anim Sci. 1999;77:1155-61.

49. Restle J, Pacheco PS, Pascoal LL, Pádua JT, Moletta JL, Freitas AKd, et al. Efeito da pastagem, da produção e da composição do leite no desempenho de bezerros de diferentes grupos genéticos. R Bras Zootec. 2004;33:691-703.

50. Almeida DM, Marcondes MI, Renno LN, de Barros LV, Cabral CHA, Martins LS, et al. Estimation of daily milk yield of Nellore cows grazing tropical pastures. Trop Anim Health Prod. 2018;50:1771-7. 
546 51. Cerdótes L, Restle J, Alves Filho DC, Nörnberg MFBL, Nörnberg JL, Heck I, et al. 547 Production and composition of milk of cows of four genetic groups submitted to two 548 feeding managements during the lactation period. R Bras Zootec. 2004;33:610-22.

549 52. Fiss CF, Wilton JW. Contribution of breed, cow weight, and milk yield to the traits of 550 heifers and cows in four beef breeding systems. J Anim Sci. 1992;70:3686-96.

551

552

553

554

555

556

557

558

559

560

561

562

53. Richardson F, Oliver J, Clarke G. Analysis of some factors which affect the productivity of beef cows and of their calves in a marginal rainfall area of Rhodesia 2 . The yield and composition of milk of suckling cows. Anim Sci. 1977;25:359-72.

54. Schmidt GH, Van Vleck LD. Bases científicas de la producción lechera. Zaragosa: Acríbia; 1976.

55. Maynard LA, Loosli JK, Hintz HF, Warner RG. Nutrição animal. 3rd ed. Rio de Janeiro: Freitas Bastos; 1984.

56. Barbosa SBP, Ramalho RP, Monardes HG, Dias FM, Santos DC, Batista ÂMV. Milk and fat production of crossbred Holstein-Gir cows (Bos taurus taurus-Bos taurus indicus) in the agreste region of the Brazilian state of Pernambuco. Genet Mol Biol. 2008;31:46874. 
Table 1 Means and standard errors (within parentheses) for lactation curve parameters ' $a$ ' and ' $k$ ', peak production (PP), week of peak lactation (WP), total production in 210 days of lactation (TP210), persistence (PER), and calf weaning weight adjusted to 210 days (CW210), obtained by mechanical milking (MM) and calf weight difference (CWD) methods, according to breed composition of the cow.

\begin{tabular}{|c|c|c|c|c|c|c|c|c|}
\hline \multirow{2}{*}{ MM } & \multicolumn{8}{|c|}{ Breed composition of the cow $^{1}$} \\
\hline & ANAN & ANHH & ANNE & CRAN & HHAN & HHHH & NEAN & NENE \\
\hline$a$ & $0.521^{\mathrm{ab}}(0.06)$ & $0.282^{\mathrm{b}}(0.07)$ & $0.539^{\mathrm{ab}}(0.06)$ & $0.368^{\mathrm{b}}(0.04)$ & $0.507^{\mathrm{ab}}(0.05)$ & $0.326^{\mathrm{b}}(0.07)$ & $0.436^{\mathrm{ab}}(0.05)$ & $0.727^{\mathrm{a}}(0.1)$ \\
\hline$k$ & $0.114^{\mathrm{bc}}(0.01)$ & $0.144^{\mathrm{ab}}(0.01)$ & $0.106^{\mathrm{c}}(0.01)$ & $0.120^{\mathrm{bc}}(0.01)$ & $0.119^{\mathrm{bc}}(0.01)$ & $0.158^{\mathrm{a}}(0.01)$ & $0.106^{\mathrm{c}}(0.01)$ & $0.104^{\mathrm{c}}(0.01)$ \\
\hline $\mathrm{PP}, \mathrm{kg}$ & $7.69^{c}(0.5)$ & $10.97^{\mathrm{a}}(0.6)$ & $9.56^{\mathrm{ab}}(0.6)$ & $10.31^{\mathrm{a}}(0.4)$ & $8.49^{\mathrm{bc}}(0.4)$ & $8.62^{\mathrm{abc}}(0.6)$ & $9.77^{\mathrm{ab}}(0.5)$ & $7.31^{\mathrm{c}}(0.8)$ \\
\hline WP, week & $9.08^{\mathrm{bc}}(0.5)$ & $7.32^{\mathrm{ab}}(0.6)$ & $10.60^{\mathrm{c}}(0.5)$ & $8.72^{\mathrm{ab}}(0.4)$ & $8.94^{\text {bc }}(0.4)$ & $6.79^{\mathrm{a}}(0.6)$ & $9.83^{\mathrm{c}}(0.4)$ & $9.39^{\mathrm{bc}}(0.8)$ \\
\hline TP210, kg & $1007.7^{\mathrm{b}}(50.0)$ & $1246.1^{\mathrm{a}}(65.7)$ & $1253.9^{\mathrm{a}}(59.1)$ & $1231.6^{\mathrm{a}}(43.7)$ & $1018.9^{\mathrm{b}}(47.3)$ & $981.2^{\mathrm{b}}(62.1)$ & $1300.2^{\mathrm{a}}(51.3)$ & $969.6^{\mathrm{b}}(76.4)$ \\
\hline PER, g/day & $-26.7^{\mathrm{b}}(2.8)$ & $-34.3^{\mathrm{ab}}(3.7)$ & $-30.7^{\mathrm{ab}}(2.99)$ & $-35.13^{\mathrm{a}}(2.2)$ & $-30.0^{\mathrm{ab}}(2.7)$ & $-34.9^{\mathrm{ab}}(3.5)$ & $-29.4^{\mathrm{ab}}(2.7)$ & $-24.4^{\mathrm{ab}}(4.1)$ \\
\hline \multicolumn{9}{|l|}{ CWD } \\
\hline$a$ & $0.479^{\mathrm{b}}(0.05)$ & $0.419^{\mathrm{b}}(0.09)$ & $0.523^{\mathrm{a}}(0.07)$ & $0.441^{\mathrm{b}}(0.04)$ & $0.440^{\mathrm{b}}(0.05)$ & $0.373^{\mathrm{b}}(0.08)$ & $0.574^{\mathrm{b}}(0.05)$ & $0.931^{\mathrm{a}}(0.08)$ \\
\hline$k$ & $0.130^{\mathrm{ab}}(0.01)$ & $0.132^{\mathrm{ab}}(0.02)$ & $0.110^{\mathrm{b}}(0.01)$ & $0.117^{\mathrm{b}}(0.01)$ & $0.134^{\mathrm{ab}}(0.01)$ & $0.174^{\mathrm{a}}(0.01)$ & $0.112^{\mathrm{b}}(0.01)$ & $0.103^{\mathrm{b}}(0.02)$ \\
\hline $\mathrm{PP}, \mathrm{kg}$ & $6.9^{\mathrm{ab}}(0.4)$ & $7.7^{\mathrm{ab}}(0.7)$ & $7.4^{\mathrm{ab}}(0.5)$ & $7.8^{\mathrm{a}}(0.3)$ & $7.3^{\mathrm{ab}}(0.3)$ & $7.4^{\mathrm{ab}}(0.5)$ & $6.8^{\mathrm{ab}}(0.4)$ & $5.2^{\mathrm{b}}(0.6)$ \\
\hline WP, week & $8.28^{\mathrm{ab}}(0.6)$ & $8.37^{\mathrm{ab}}(0.9)$ & $9.45^{\mathrm{ab}}(0.7)$ & $9.01^{\mathrm{ab}}(0.5)$ & $8.18^{\mathrm{ab}}(0.5)$ & $6.92^{\mathrm{b}}(0.8)$ & $9.66^{\mathrm{a}}(0.5)$ & $11.18^{\mathrm{a}}(0.9)$ \\
\hline $\mathrm{TP} 210, \mathrm{~kg}$ & $925.31^{\mathrm{ab}}(59.6)$ & $1017.6^{\mathrm{ab}}(95.9)$ & $1053.5^{\mathrm{ab}}(75.6)$ & $1104.1^{\mathrm{a}}(48.9)$ & $944.6^{\mathrm{ab}}(51.9)$ & $848.4^{\mathrm{ab}}(80.2)$ & $988.1^{\mathrm{ab}}(54.5)$ & $774.4^{\mathrm{b}}(91.1)$ \\
\hline PER, g/day & $-32.2(3.9)$ & $-40.9(6.3)$ & $-34.7(5.0)$ & $-41.5(3.2)$ & $-42.5(3.3)$ & $-42.7(5.3)$ & $-32.8(3.8)$ & $-31.7(6.6)$ \\
\hline CW210, kg & $193.61^{\mathrm{bc}}(5.1)$ & $213.07^{\mathrm{ab}}(6.7)$ & $223.34^{\mathrm{a}}(6.0)$ & $220.45^{\mathrm{a}}(4.1)$ & $192.8^{\mathrm{bc}}(4.5)$ & $183.67^{\mathrm{c}}(6.6)$ & $221.3^{\mathrm{a}}(5.0)$ & $189.9^{\mathrm{bc}}(8.1)$ \\
\hline
\end{tabular}

${ }^{\mathrm{a}-\mathrm{c}}$ Means within a line with different superscripts differ $(P<0.05) .{ }^{1} \mathrm{ANAN}=$ Angus; ANHH = Angus-Hereford; ANNE $=$ Angus-Nellore; CRAN $=$ Caracu-Angus $;$ HHAN = Hereford-Angus HHHH = Hereford ;EAN = Nellore-Angus; NENE = Nellore. 
Table 2 Means and standard errors (within parentheses) from lactation curve parameters ' $a$ ' and ' $k$,' peak production (PP), week of peak lactation (WP), total production in 210 days of lactation (TP210), persistence (PER), and calf weaning weight adjusted to 210 days (CW210), obtained by mechanical milking (MM) and calf weight difference (CWD) methods, according to calving season, sex and breed of sire.

\begin{tabular}{|c|c|c|c|c|c|c|}
\hline \multirow{2}{*}{ MM } & \multicolumn{2}{|c|}{ Calving season } & \multicolumn{2}{|c|}{ Sex } & \multicolumn{2}{|c|}{ Breed of sire } \\
\hline & Beginning & End & Male & Female & Brangus & Braford \\
\hline$a$ & $0.424(0.04)$ & $0.502(0.04)$ & $0.477(0.04)$ & $0.449(0.04)$ & $0.459(0.04)$ & $0.467(0.04)$ \\
\hline$k$ & $0.117(0.005)$ & $0.125(0.005)$ & $0.119(0.004)$ & $0.123(0.005)$ & $0.123(0.005)$ & $0.119(0.005)$ \\
\hline $\mathrm{PP}, \mathrm{kg}$ & $9.61^{\mathrm{a}}(0.4)$ & $8.57^{\mathrm{b}}(0.3)$ & $9.00(0.3)$ & $9.18(0.3)$ & $9.10(0.3)$ & $9.09(0.4)$ \\
\hline WP, week & $8.98(0.4)$ & $8.68(0.3)$ & $8.84(0.3)$ & $8.82(0.3)$ & $8.65(0.3)$ & $9.02(0.3)$ \\
\hline TP210, kg & $1219.04^{\mathrm{a}}(41.8)$ & $1033.3^{\mathrm{b}}(37.9)$ & $1116.6(38.4)$ & $1135.1(38.3)$ & $1131(35.9)$ & $1120(40.8)$ \\
\hline PER, g/day & $-32.05(2.3)$ & $-29.38(2.4)$ & $-30.72(2.2)$ & $-30.71(2.2)$ & $-30.32(2.2)$ & $-31.1(2.3)$ \\
\hline \multicolumn{7}{|l|}{ CWD } \\
\hline$a$ & $0.564(0.04)$ & $0.482(0.04)$ & $0.528(0.04)$ & $0.516(0.04)$ & $0.50(0.04)$ & $0.54(0.04)$ \\
\hline$k$ & $0.106^{\mathrm{a}}(0.01)$ & $0.100^{\mathrm{b}}(0.01)$ & $0.126(0.01)$ & $0.126(0.01)$ & $0.13(0.01)$ & $0.13(0.01)$ \\
\hline $\mathrm{PP}, \mathrm{kg}$ & $7.7(0.3)$ & $6.9(0.3)$ & $7.13(0.3)$ & $7.0(0.3)$ & $7.4(0.3)$ & $6.8(0.3)$ \\
\hline WP, week & $9.8^{\mathrm{a}}(0.4)$ & $7.9^{\mathrm{b}}(0.4)$ & $8.7(0.4)$ & $9.1(0.4)$ & $9.04(0.4)$ & $8.72(0.4)$ \\
\hline TP210, kg & $1053.9^{\mathrm{a}}(44.6)$ & $860.12^{b}(42.2)$ & $955.86(41.4)$ & $958.21(41.2)$ & $1008.8(39.7)$ & $905.3(43.3)$ \\
\hline PER, g/day & $-37.07(3.0)$ & $-38.49(2.9)$ & $-39.0(2.8)$ & $-36.5(2.7)$ & $-39.6(2.6)$ & $-35.9(2.9)$ \\
\hline CW210, kg & $213.46^{\mathrm{a}}(3.9)$ & $196.11^{b}(3.6)$ & $207.0(3.5)$ & $202.6(3.6)$ & $203.9(3.4)$ & $205.7(3.7)$ \\
\hline
\end{tabular}

${ }^{\mathrm{a}, \mathrm{b}}$ Means within a line and factor with different superscripts differ $(P<0.05)$. 
Table 3 Means and standard errors (within parentheses) from lactation curve parameters ' $a$ ' and ' $k$ ', peak production (PP), week of peak lactation (WP), total production in 210 days of lactation (TP210), persistence (PER), and calf weaning weight adjusted to 210 days (CW210), obtained by mechanical milking (MM) and calf weight difference (CWD) methods, according to the calving order.

\begin{tabular}{|c|c|c|c|c|c|c|c|c|c|}
\hline \multirow{2}{*}{ MM } & \multicolumn{9}{|c|}{ Calving order } \\
\hline & 3.1 & 4.1 & 4.18 & 4.2 & 5.2 & 5.3 & 6.2 & 6.3 & 6.4 \\
\hline \multirow{2}{*}{$a$} & $0.563^{\mathrm{ab}}$ & $0.365^{\mathrm{ab}}$ & $0.603^{\mathrm{ab}}$ & $0.604^{\mathrm{a}}$ & $0.414^{\mathrm{ab}}$ & $0.387^{\mathrm{b}}$ & $0.446^{\mathrm{ab}}$ & $0.356^{\mathrm{ab}}$ & $0.432^{\mathrm{ab}}$ \\
\hline & $(0.03)$ & $(0.1)$ & $(0.1)$ & $(0.04)$ & $(0.1)$ & $(0.06)$ & $(0.16)$ & $(0.1)$ & $(0.1)$ \\
\hline \multirow{2}{*}{$k$} & 0.127 & 0.130 & 0.113 & 0.110 & 0.121 & 0.124 & 0.118 & 0.135 & 0.114 \\
\hline & $(0.003)$ & $(0.01)$ & $(0.01)$ & $(0.004)$ & $(0.01)$ & $(0.01)$ & $(0.02)$ & $(0.01)$ & $(0.01)$ \\
\hline $\mathrm{PP}, \mathrm{kg}$ & $6.69^{c}(0.2)$ & $9.39^{\mathrm{ab}}(0.8)$ & $7.39^{\mathrm{bc}}(0.8)$ & $7.48^{\mathrm{bc}}(0.3)$ & $9.57^{\mathrm{ab}}(0.6)$ & $9.17^{\mathrm{ab}}(0.5)$ & $9.40^{\mathrm{ab}}(1.4)$ & $11.74^{\mathrm{a}}(0.8)$ & $11.02^{\mathrm{a}}(0.9)$ \\
\hline WP, week & $8.54^{\mathrm{b}}(0.2)$ & $8.09^{\mathrm{ab}}(0.8)$ & $9.57^{\mathrm{ab}}(0.8)$ & $9.91^{\mathrm{a}}(0.3)$ & $8.59^{\mathrm{ab}}(0.6)$ & $8.41^{\mathrm{ab}}(0.5)$ & $8.61^{\mathrm{ab}}(1.4)$ & $7.93^{\mathrm{ab}}(0.8)$ & $9.85^{\mathrm{a}}(0.9)$ \\
\hline \multirow{2}{*}{$\mathrm{TP} 210, \mathrm{~kg}$} & $879.9^{c}$ & $1241.6^{\mathrm{ab}}$ & $908.5^{\mathrm{bc}}$ & $1028^{\mathrm{ab}}$ & $1097.9^{\mathrm{ab}}$ & $1147.8^{\mathrm{ab}}$ & $1279.1^{\mathrm{ab}}$ & $1325.4^{\mathrm{a}}$ & $1227.3^{\mathrm{ab}}$ \\
\hline & $(22.3)$ & (80.1) & $(74.4)$ & $(31.3)$ & (69.8) & (53.8) & $(145.1)$ & $(97.1)$ & $(143.3)$ \\
\hline PER, g/day & $-27.3(1.2)$ & $-38.7(4.5)$ & $-22.7(3.9)$ & $-26.8(1.8)$ & $-36.7(3.3)$ & $-33.3(3.0)$ & $-18.2(11.9)$ & $-43.1(8.4)$ & $-29.4(5.2)$ \\
\hline \multicolumn{10}{|l|}{ CWD } \\
\hline$a$ & $0.536(0.03)$ & $0.462(0.1)$ & $0.566(0.1)$ & $0.502(0.05)$ & $0.487(0.1)$ & $0.579(0.1)$ & - & - & - \\
\hline$k$ & $0.138(0.005)$ & $0.126(0.02)$ & $0.114(0.01)$ & $0.124(0.01)$ & $0.137(0.02)$ & $0.119(0.01)$ & - & - & - \\
\hline $\mathrm{PP}, \mathrm{kg}$ & $6.5(0.2)$ & $7.8(0.7)$ & $6.9(0.5)$ & $7.0(0.3)$ & $7.3(0.7)$ & $6.9(0.5)$ & - & - & - \\
\hline WP, week & $8.4(0.3)$ & $9.1(1.1)$ & $9.3(0.8)$ & $8.6(0.5)$ & $8.5(1.0)$ & $9.4(0.8)$ & - & - & - \\
\hline TP210, kg & $840.7(29.2)$ & $1070.6(106.2)$ & $965.8(74.9)$ & $959.5(48.0)$ & $945.6(96.0)$ & $960.0(75.3)$ & - & - & - \\
\hline PER, g/day & $-34.9(2.0)$ & $-51.5(7.1)$ & $-33.3(5.1)$ & $-36.3(3.2)$ & $-34.9(6.9)$ & $-35.8(5.3)$ & - & - & - \\
\hline \multirow{2}{*}{ CW210, kg } & $186.52^{\mathrm{bc}}$ & $214.13^{\mathrm{a}}$ & $194.54^{\mathrm{ab}}$ & $192.60^{\mathrm{bc}}$ & $203.70^{\mathrm{ab}}$ & $206.84^{\mathrm{ab}}$ & $213.84^{\mathrm{ab}}$ & $218.11^{\mathrm{a}}$ & $212.82^{\mathrm{ab}}$ \\
\hline & (2.4) & $(7.8)$ & $(7.4)$ & (3.3) & (6.2) & $(5.4)$ & $(13.5)$ & $(7.7)$ & $(8.9)$ \\
\hline
\end{tabular}

${ }^{\mathrm{a}-\mathrm{c}}$ Means within a line with different superscripts differ $(P<0.05)$. 
Table 4 Means and standard errors (within parentheses) of fat, protein, lactose and total solids percentages in milk according to the cow's racial composition.

\begin{tabular}{|c|c|c|c|c|c|c|c|c|}
\hline \multirow{2}{*}{ Milk components, $\%$} & \multicolumn{8}{|c|}{ Breed composition of the cow ${ }^{1}$} \\
\hline & ANAN & ANHH & ANNE & CRAN & HHAN & HHHH & NEAN & NENE \\
\hline Fat & $3.33^{\mathrm{b}}(0.09)$ & $3.59^{\mathrm{ab}}(0.13)$ & $4.02^{\mathrm{a}}(0.13)$ & $3.91^{\mathrm{a}}(0.08)$ & $3.66^{\mathrm{ab}}(0.09)$ & $3.88^{\mathrm{a}}(0.13)$ & $4.05^{\mathrm{a}}(0.10)$ & $3.81^{\mathrm{ab}}(0.16)$ \\
\hline Protein & $2.91^{\mathrm{b}}(0.04)$ & $2.98^{\mathrm{b}}(0.05)$ & $3.13^{\mathrm{ab}}(0.05)$ & $3.13^{\mathrm{ab}}(0.03)$ & $3.03^{\mathrm{b}}(0.03)$ & $3.28^{\mathrm{a}}(0.05)$ & $3.10^{\mathrm{ab}}(0.04)$ & $3.30^{\mathrm{a}}(0.06)$ \\
\hline Lactose & $4.65^{\mathrm{b}}(0.03)$ & $4.59^{\mathrm{b}}(0.03)$ & $4.80^{\mathrm{a}}(0.03)$ & $4.64^{\mathrm{b}}(0.02)$ & $4.61^{\mathrm{b}}(0.02)$ & $4.59^{\mathrm{b}}(0.03)$ & $4.86^{\mathrm{a}}(0.03)$ & $4.67^{\mathrm{b}}(0.04)$ \\
\hline Total solids & $11.7^{\mathrm{b}}(0.12)$ & $12.0^{\mathrm{b}}(0.16)$ & $12.9^{\mathrm{a}}(0.16)$ & $12.5^{\mathrm{ab}}(0.11)$ & $12.2^{\mathrm{ab}}(0.12)$ & $12.7^{\mathrm{a}}(0.17)$ & $12.9^{\mathrm{a}}(0.13)$ & $12.8^{\mathrm{a}}(0.21)$ \\
\hline
\end{tabular}

${ }^{\mathrm{a}, \mathrm{b}}$ Means within a line with different superscripts $\operatorname{differ}(P<0.05)$.

${ }^{1}$ ANAN = Angus; ANHH = Angus-Hereford ANNE = Angus-Nellore; CRAN = Caracu-Angus; HHAN = Hereford-Angus; HHHH = Hereford; NEAN = Nellore-Angus; NENE $=$ Nellore 
Table 5 Means and standard errors (within parentheses) of fat, protein, lactose and total solids percentages in milk obtained at 40-60 (beginning), 90-110 (middle), and 180-210 days of lactation.

\begin{tabular}{lccc}
\hline \multirow{2}{*}{ Milk components, $\%$} & \multicolumn{3}{c}{ Lactation period } \\
\cline { 2 - 4 } & Beginning & Middle & End \\
\hline Fat & $3.39^{\mathrm{a}}(0.06)$ & $3.56^{\mathrm{a}}(0.06)$ & $4.39^{\mathrm{b}}(0.06)$ \\
Protein & $2.86^{\mathrm{a}}(0.02)$ & $3.07^{\mathrm{b}}(0.02)$ & $3.40^{\mathrm{c}}(0.02)$ \\
Lactose & $4.77^{\mathrm{a}}(0.02)$ & $4.80^{\mathrm{a}}(0.01)$ & $4.50^{\mathrm{b}}(0.02)$ \\
Total solids & $11.9^{\mathrm{a}}(0.149)$ & $12.3^{\mathrm{b}}(0.140)$ & $13.3^{\mathrm{c}}(0.145)$ \\
\hline
\end{tabular}

${ }^{\mathrm{a}-\mathrm{c}}$ Means within a line with different superscripts differ $(P<0.05)$.

${ }^{1}$ ANAN $=$ Angus $;$ ANHH $=$ Angus-Hereford $;$ ANNE $=$ Angus-Nellore $;$ CRAN $=$ CaracuAngus; HHAN = Hereford-Angus; $\mathrm{HHHH}=$ Hereford $;$ NEAN = Nellore-Angus; NENE = Nellore. 


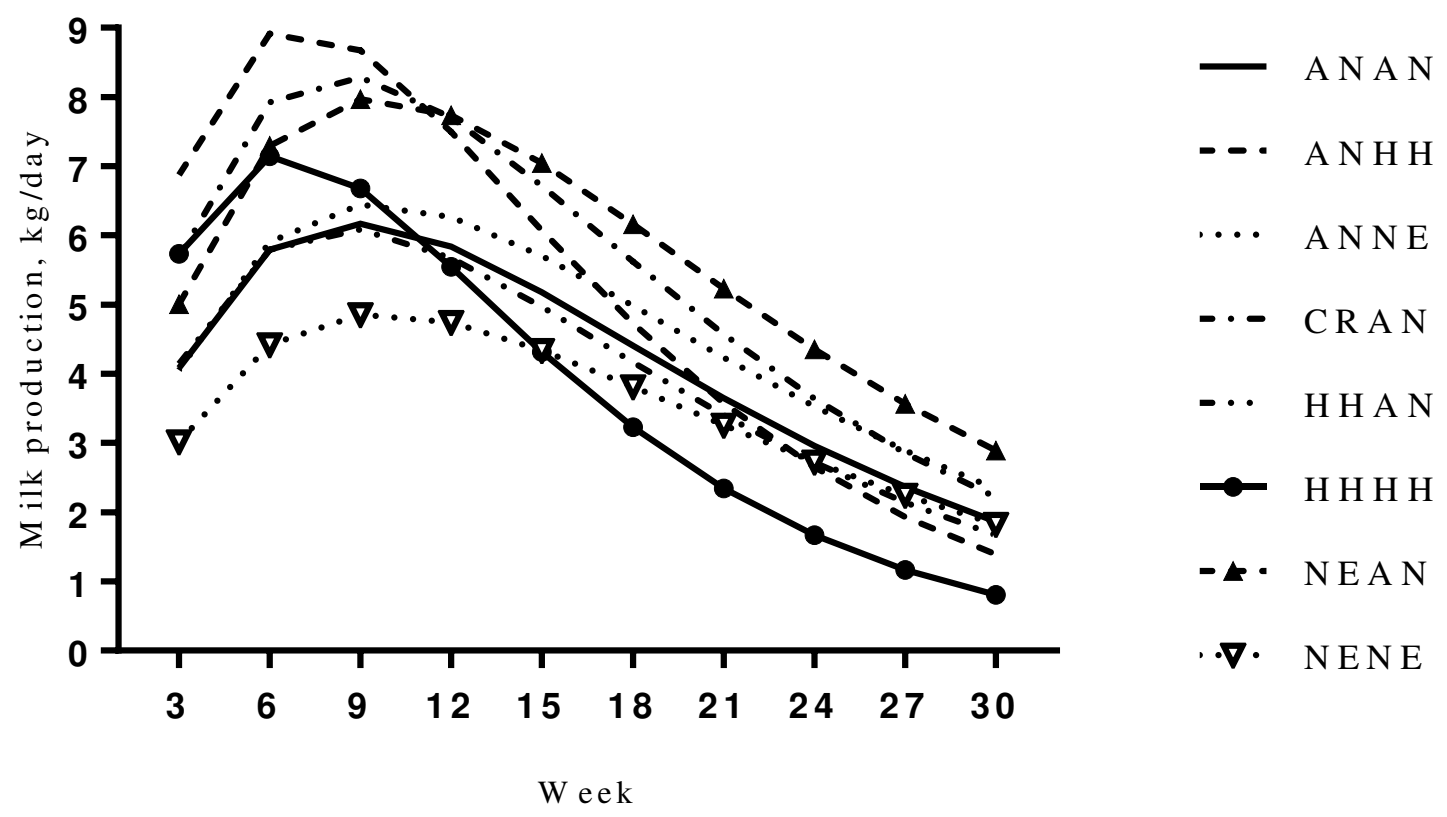

Fig. 1 Lactation curves obtained by mechanical milking (MM) of Angus (ANAN), AngusHereford (ANHH), Angus-Nellore (ANNE), Caracu-Angus (CRAN), Hereford-Angus (HHAN), Hereford (HHHH), Nellore-Angus (NEAN), and Nellore (NENE) cows. 


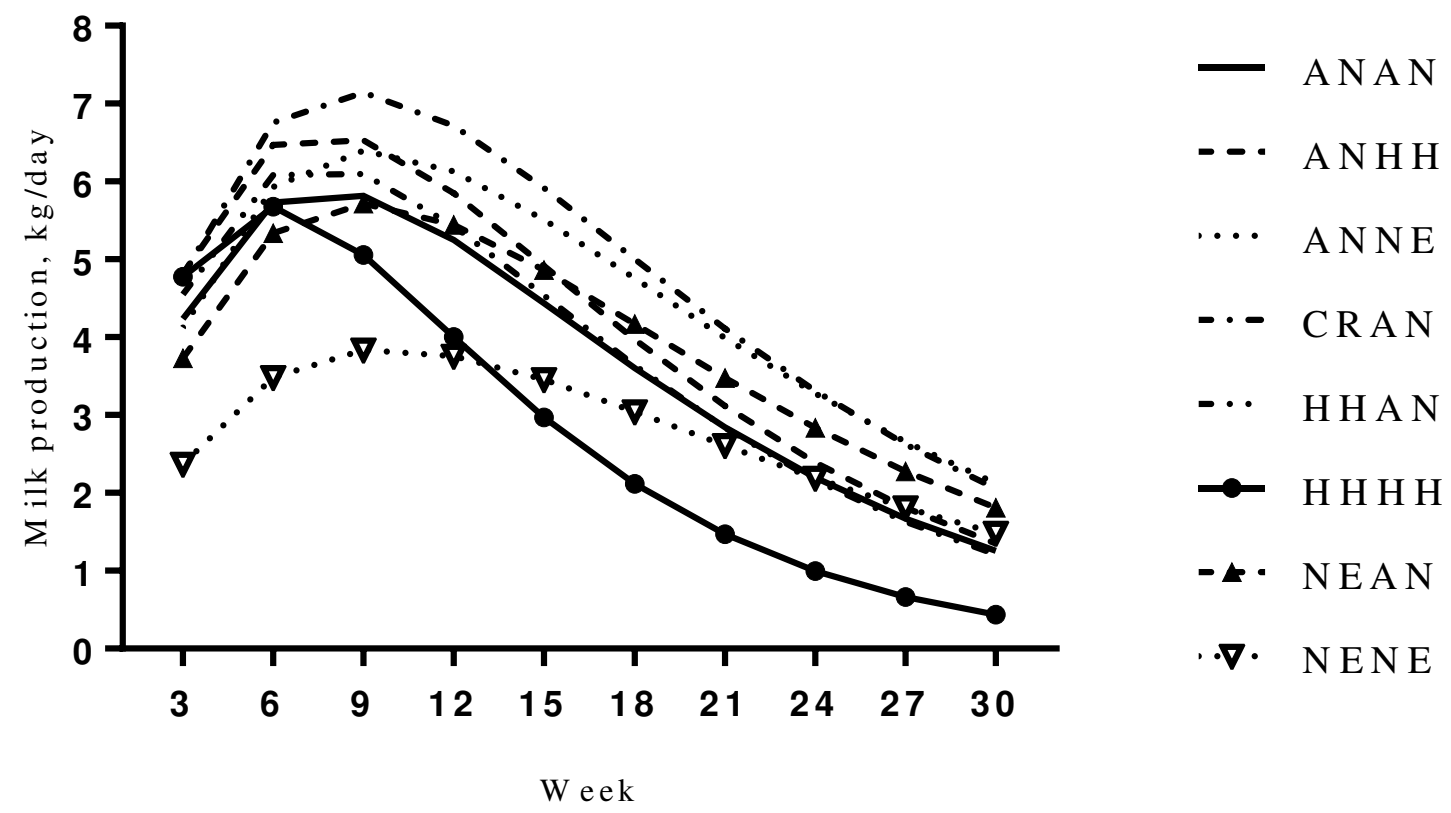

Fig. 2 Lactation curves obtained by calf weight difference before and after nursing (CWD) of Angus (ANAN), Angus-Hereford (ANHH), Angus-Nellore (ANNE), Caracu-Angus (CRAN), Hereford-Angus (HHAN), Hereford (HHHH), Nellore-Angus (NEAN), and Nellore (NENE) cows. 
Figures
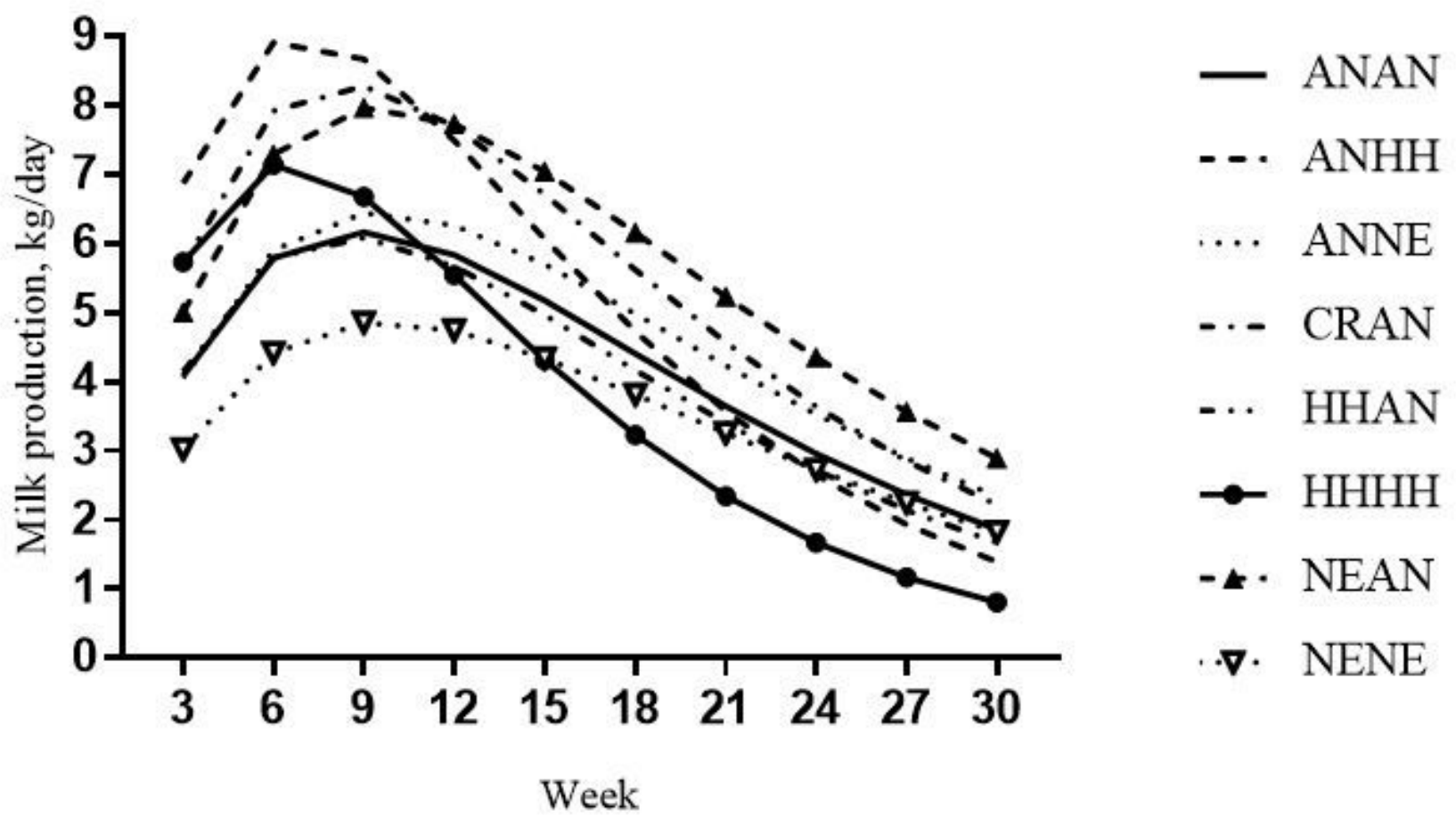

Figure 1

Lactation curves obtained by mechanical milking (MM) of Angus (ANAN), Angus-Hereford (ANHH), Angus-Nellore (ANNE), Caracu-Angus (CRAN), Hereford-Angus (HHAN), Hereford (HHHH), Nellore-Angus (NEAN), and Nellore (NENE) cows. 


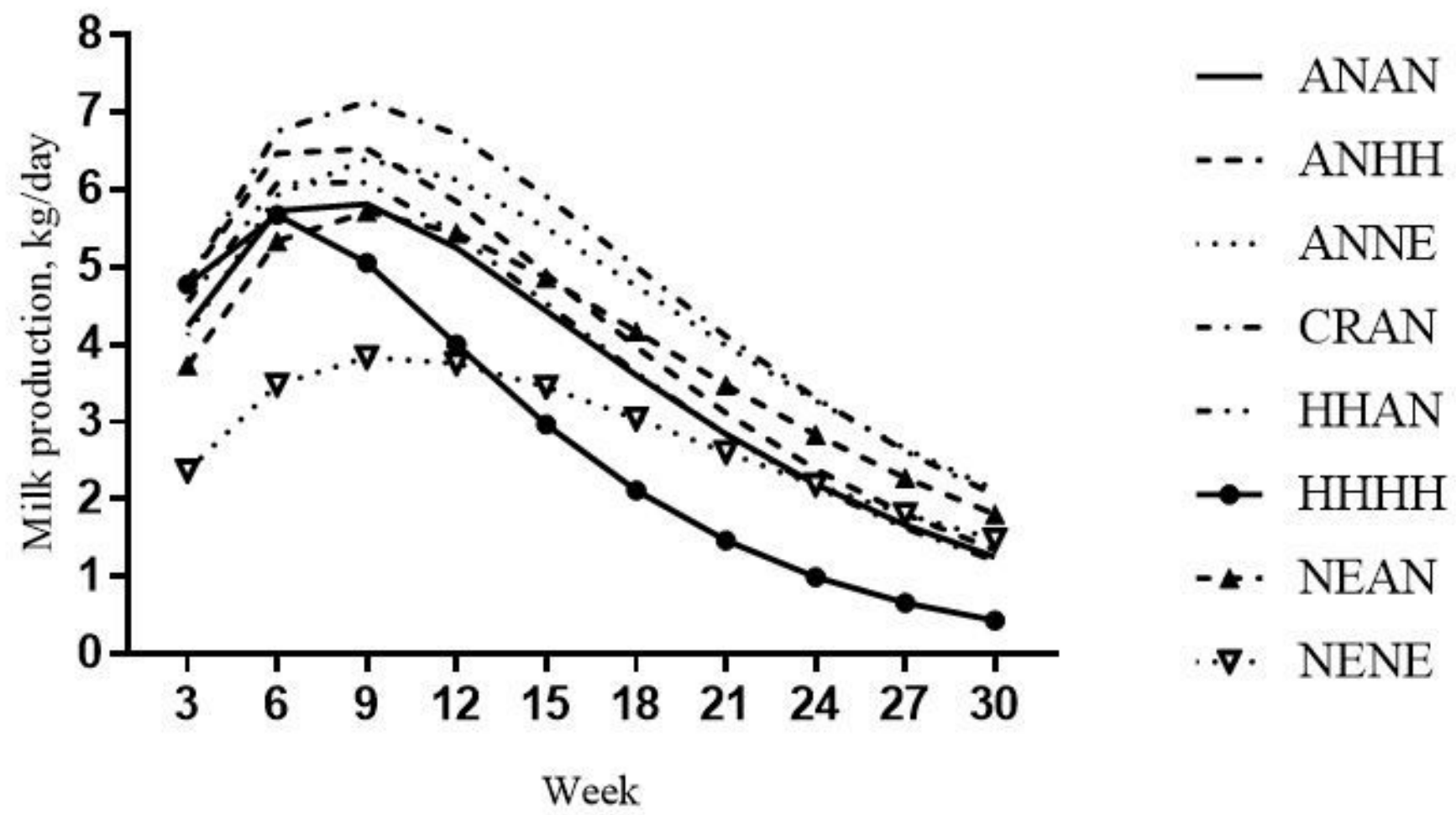

Figure 2

Lactation curves obtained by calf weight difference before and after nursing (CWD) of Angus (ANAN), Angus-Hereford (ANHH), Angus-Nellore (ANNE), Caracu-Angus (CRAN), Hereford-Angus (HHAN), Hereford $(\mathrm{HHHH})$, Nellore-Angus (NEAN), and Nellore (NENE) cows. 